\title{
A multi-ingredient containing, proteins, carbohydrate and creatine does not attenuate humoral immune response or performance decrease compared to carbohydrate during resistance training
}

\author{
Nadia Ashrafi' ${ }^{2}$, Marcos Seijo ${ }^{1}$, Frank Pullen², Birthe V Nielsen², Joshua Smith', Christian Wilkinson', Yue Fu', \\ Jack Miller ${ }^{1}$, Eneko Larumbe-Zabala ${ }^{3}$, Fernando Naclerio ${ }^{1}$
}

From The Twelfth International Society of Sports Nutrition (ISSN) Conference and Expo

Austin, TX, USA. 11-13 June 2015

\section{Background}

Nowadays, only carbohydrate has shown to be an effective countermeasure to exercise-induced immune dysfunction while the effect of protein remains controversial. The purpose of this study was to investigate the acute effects of a commercially available multi-nutrient supplement on performance and salivary markers of humoral immunity, following a bout of circuit resistance training in young athletes.

\section{Methods}

Twelve recreationally resistance-trained males (age: $22 \pm$ 1.4 years; body mass $79 \pm 9.78 \mathrm{~kg} ; 1.81 \pm 0.07 \mathrm{~m}$ height) volunteered to participate in the study completing 2 randomised controlled circuit resistance training sessions (CT). Participants ingested 2 doses of $500 \mathrm{ml}$ of water mixed $60 \mathrm{~g}$ of a multi-ingredient (MTN) containing whey proteins, carbohydrate, creatine, HMB and sodium bicarbonate or maltodextrin (PL). Beverages were consumed (3 doses of $\sim 166 \mathrm{ml}$ ) during and after the workout $(1 \times$ $500 \mathrm{ml})$. Both MTN and PL looks the same colour and flavour and provide a similar amount of calories $(\sim 230$ per serving). CT involved three rounds of 7 resistance exercises (CMJs, Bench Press, Parallel-Squat, Upright row, Alternate Lunges, Dead Lift, Push-press, Abdominals)

\footnotetext{
* Correspondence: N.Ashrafi@greenwich.ac.uk

${ }^{2}$ Faculty of Engineering and Science, University of Greenwich, Chatham Maritime, Kent, ME4 4TB, UK

Full list of author information is available at the end of the article
}

followed by 1 min rest. Participants performed 12 repetitions at $70 \% 1 \mathrm{RM}$ in each of the exercises with no rest in between (only the time to change from one exercise to the next).

Measurements included pre and post $(30 \mathrm{~min}$ and $60 \mathrm{~min}$ ) salivary markers of humoral immune response: Antimicrobial Peptide, Alpha Defensins (HNP 1-3). The total $\mathrm{kg}$ lifted per exercise and in the overall workout was considered as indicator of performance. ANOVA design and Cohen d effect sizes (ES) were used to analyse potential differences between times and treatment conditions.

\section{Results}

No significant differences were observed between the total weight $(\mathrm{kg})$ lifted per exercise or for the entire session $(\mathrm{p}>$ $0.05)$. HNP 1-3 showed a strong trend $(\mathrm{p}=0.06)$ with a moderate effect size $(\mathrm{d}=0.53)$ at $30 \mathrm{~min}$ for the $\mathrm{CHO}$ condition [2.001 (1.95) vs $3.037(2.49) \mathrm{ng} / \mathrm{mL}]$, nevertheless, no significant differences were observed at $60 \mathrm{~min}$ with respect to the values measured at both pre [3.825 (3.21) vs $2.001(1.95) \mathrm{ng} / \mathrm{mL}]$ and $30 \mathrm{~min}[3.825(3.21) \mathrm{vs}$ $3.037(2.49) \mathrm{ng} / \mathrm{mL}$ ]. On the other side, HNP 1-3 did not increase at either $30 \mathrm{~min}$ [2.464 (3.31) vs 3.656 (3.22) $\mathrm{ng} / \mathrm{mL}]$ or $60 \mathrm{~min}$ [2.464(3.31) vs $2.387(2.46) \mathrm{ng} / \mathrm{mL}]$ post workout for the MTN treatment condition. No differences were observed between the two tested treatment conditions for the three analysed times points (pre, post $30 \mathrm{~min}$ and post $60 \mathrm{~min}$ ). 


\section{Conclusion}

Ingesting both MTN and $\mathrm{CHO}$ supplements during and after a circuit resistance-training workout, resulted in no impact on performance. However, even when both nutritional interventions were effective to attenuate the increase of antimicrobial peptide alpha-defensins, MTN showed a stronger effect to blunt exercise-induced immune-dysfunction. These results did not support the notion that only carbohydrate with no added proteins is the only effective nutritional countermeasure against the transient post exercise immunosuppression.

\section{Acknowledgements}

The authors would like to thank all participants and Kelly Cooper for their help and support during the collection data process.

\section{Authors' details}

${ }^{1}$ Centre for Sport Science and Human Performance, University of Greenwich, Chatham Maritime, Kent, ME4 4TB, UK. ${ }^{2}$ Faculty of Engineering and Science, University of Greenwich, Chatham Maritime, Kent, ME4 4TB, UK. ${ }^{3}$ Clinical Research Institute, Texas Tech University Health Science Center, TX, USA.

Published: 21 September 2015

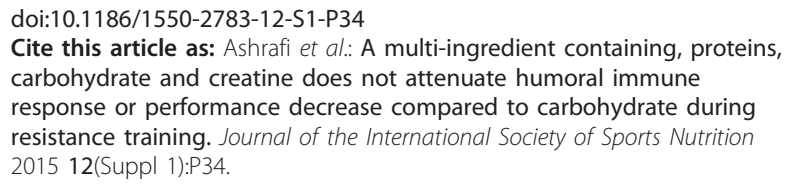

Submit your next manuscript to BioMed Central and take full advantage of:

- Convenient online submission

- Thorough peer review

- No space constraints or color figure charges

- Immediate publication on acceptance

- Inclusion in PubMed, CAS, Scopus and Google Scholar

- Research which is freely available for redistribution 